\title{
Managing the Past in Urban Portraitures in fin-de-siècle Saxon Transylvania
}

Journal of Urban History 2017, Vol. 43(4) 65I-660

(c) The Author(s) 2017

Reprints and permissions: sagepub.com/journalsPermissions.nav DOI: $10.1177 / 0096144217705350$ journals.sagepub.com/home/juh

@SAGE

\section{Borbála Zsuzsanna Török'}

\begin{abstract}
The article addresses the cultural appropriation of multiethnic provincial urban spaces in Dualist Hungary. Scholarly topographies of towns experienced a boom at the turn of the century and were produced and marketed in the framework of collaborative enterprises, whether in the shape of state-sponsored committees or societies organized on voluntary basis. In Transylvania, the oldest academic institutions dedicated to such work were primarily the so-called Landeskunde (in Hungarian: honismeret) societies. The article explores the ways in which the social background, the target audience, and the material resources of the societies determined the outcome of the urban mapping by focusing on the multiethnic Transylvanian city Hermannstadt (in Romanian: Sibiu, in Hungarian: Nagyszeben). Here ethno-linguistic affiliations created the most fundamental dividing line that cut across the intellectual milieus during the time under scrutiny. The resulting urban mono-cultural topographies were part of shaping national historiographies, which in the Saxon case emphasized the cultural distinctness of the Transylvanian Lutheran Germans, and played down the difference between the towns and countryside.
\end{abstract}

\section{Keywords}

Transylvania, urban culture, cultural topography

What possibilities had educated ladies and gentlemen from the provincial towns in fin-de-siècle Austro-Hungarian Monarchy to inform themselves about the cultural space in which they lived? On what infrastructural background could they rely and what kind of information networks did aid such an inquiry? What kind of scholarly paradigms, what methods, and what kind of political frameworks determined the production of cultural topographies in the multiethnic cities? How was this knowledge structured and how was it transmitted?

Let us take, for instance, a mid-rank German-speaking bank officer from the Hermannstädter Allgemeine Sparkasse (Savings Bank of Hermannstadt) in the Transylvanian city of same name (Romanian: Sibiu, Hungarian: Nagyszeben). The choice of the town is justified by the international renown of the former administrative heart of Transylvania and center of the ancient Saxon self-government, administrative seat of the county Szeben in Hungary during the AustroHungarian Compromise. The cultural infrastructure had been traditionally dense in this city, where the German, that is, Transylvanian Saxon majority determined the cityscape with its

'Zukunftskolleg, University of Konstanz, Konstanz, Germany

\section{Corresponding Author:}

Borbála Zsuzsanna Török, University of Konstanz, PO Box 216, Konstanz 78457, Germany.

Email: borbala-zsuzsanna.toeroek@uni-konstanz.de 
numerous voluntary associations, banks, schools and gymnasia, cultural and scholarly societies, including the Verein für Siebenbürgische Landeskunde (or Landeskundeverein, Association for Transylvanian Landeskunde, 1842-1947). The bastions and parts of the walls of the once fortified city had been often described in travelogues and learned treatises. ${ }^{1}$ The Brukenthal Museum, ${ }^{2}$ a jewel of baroque architecture and collecting talent, situated next to the Lutheran city parish church built in gothic style ${ }^{3}$ were further attractions of the impressive historic center, complete with the old Lutheran gymnasium, ${ }^{4}$ and several other historic buildings. Its circa one-third Romanian population also boasted a Greek Orthodox bishopric in the historic center, with the normal school for girls, ${ }^{5}$ then the savings Bank Albina, ${ }^{6}$ and the seat of the Transylvanian Romanian academy and cultural association, the Asociația Transilvană Pentru Literatura Română şi Cultura Poporului Român (or ASTRA, the Transylvanian Association for Romanian Literature and the Culture of the Romanian People, 1861-1950, newly founded in 1990) and its museum. ${ }^{7}$ There was a visible growth of descriptive material that documented the cultural landscape of the town at the turn of the century. Also, it is impossible to miss the differences, asymmetries, and divisions in the cultural mappings: there were as many as the number of well-established ethnic clusters in the town. Moreover, the German image of Hermannstadt was not identical with Romanian imaginary maps of Sibiu; these were complementary and sometimes mutually excluding cityscapes, created by distinct narratives of the city and its architecture. Last but not least, the sources and the identity of the authors lead to local chapters of the Transylvanian Saxon and Romanian learned societies. How was knowledge organized and divided up about contemporary multiethnic urban spaces? To probe the possible answers to my question, I propose a threefold thesis:

1. The scholarly topography of contemporary provincial towns was produced and marketed at the turn of the twentieth century as a collective undertaking of scholars, whether in state-sponsored committees or learned societies organized on voluntary basis. In Transylvania, the oldest academic institutions were the so-called Landeskunde (study of the fatherland, in Hungarian: honismeret) societies, the Landeskundeverein, and the Hungarian Erdélyi Múzeum Egyesület (or EME, the Transylvanian Museum Society, 1859-1950, reestablished in 1990). These, together with the ASTRA, had a key position in producing local knowledge in the vernacular languages both about the urban environment and beyond. Scholarship institutionalized by these associations called forth a specific configuration of linguistic, ethnographic, geographic, statistical, and historical knowledge about the urban space, as well as the entire regional cultural environment, based on the collection of relevant data. The exploration of the local environment complemented the more general university curricula and sometimes it constituted itself even against the former. This practice was by no means unique to the Transylvanian configuration, but characterized the entire Habsburg Monarchy and Germany.

2. My second claim is that the social background, the primary goals and the material resources and even the language use of the societies determined the outcome of the urban mapping. To grasp the logic of the locally produced urban topographies, one has to look at the social and institutional framework. Indeed, the large state-sponsored monograph series titled Magyarország vármegyéi és városai (The counties and towns of Hungary), ${ }^{8}$ that materialized in the two decades before World War I, and was the only encompassing enterprise of its kind, left historic Transylvania blank. Here the perusal of urban history became widespread in Hungarian, Romanian and German scholarship and was closely linked to the systematization of city archives and source publication in the practice of the learned societies. Their sponsors, beyond the members, were the Churches, who managed the education of the ethnic and religious minorities, the ethnically organized savings banks and associations, and partly the city councils. In the case of the Magyar institute, 
the central government too offered support. The ethnic differences between these societies were manifest in the membership, in the sponsors, and also in the scholarly outcome. The competing and entangled nationalisms conferred their dynamics to scholarship, resulting in explorations of the urban space with mutually exclusive ethno-cultural focus.

3. Hermannstadt as well as other larger Transylvanian multiethnic towns were placed in a web of scholarly communication that stretched beyond the province and spanned Vienna and the German academic cities, Budapest, and also the Romanian capitals of knowledge, Bucharest and Iași. Provincial scholarly organizations were the nods in these networks, creating ties to these "extraterritorial" academic centers, universities, and museums. The merit of such contacts was to give scientific impulses for work at home, to legitimate the quality of knowledge produced locally, and also to help putting the Transylvanian cities on the European map by selling the scholarly products abroad. Spreading knowledge about the cities of Transylvania could contribute also to tourism, where the German publications of the Landeskundeverein received most international attention. I do not find it accidental, that an English-speaking Baedeker guide to the lands of the Habsburg Monarchy from 1911 provided more information on the Transylvanian Saxon towns (especially Kronstadt and Hermannstadt) than about their non-German peers. In the following, I shall illustrate my points by focusing on "Saxon" Hermannstadt. I shall continually refer to the international cooperations and knowledge transfer in the background of locally produced urban knowledge, as well as the modalities of consuming it.

\section{The "Collecting Collective"}

If a Saxon inhabitant of Hermannstadt wished to learn more about his hometown, he might have turned to one of the publications of the Landeskundeverein, which was the chief source of local history by that time in Saxon milieus. Rather academic in character was the Archiv des Vereins für Siebenbürgische Landeskunde, ${ }^{9}$ in print since 1843. A newer, more dynamic journal was the Korrespondenzblatt, published since 1878, that monitored domestic research in the humanities and the relevant publications in Austria, the Romanian Kingdom, and Germany. ${ }^{10}$ One finds here a combination of erudite content in a digestible format, meant to satisfy both a specialized audience and interested amateurs, even "peasants and manual laborers." ${ }^{11}$ Reading the source publications and the short review essays, the readers could fill with details the historical image of their hometowns and villages, complete with monument buildings, schools, and increasingly their better known personages, teachers, and pastors.

The scholarly framework of this factual knowledge was Landeskunde. Rooted in the early modern descriptions of states, ${ }^{12}$ the knowledge field targeted the exploration of the "fatherland," its inhabitants and its physical characteristics. A German academic tradition, it gathered and published data in several disciplines, including history, geography, ethnography, statistics, and natural history. The criteria of fact-finding were originally usefulness to the local administration, yet the administrative air gradually gave place to a cultural historical perspective after the mid-century.

In the Saxon-dominated towns, it was the educated middle strata who had an interest in local cultural topographies. Gymnasium professors, Lutheran pastors, politicians, and state bureaucrats were the typical producers and consumers of the cultural goods produced by the Landeskundeverein too. ${ }^{13}$ Their increase in the ranks of the association was paralleled with strategies of communication to reach out both for specialists and for a broader audience. It is noteworthy that while the German-speaking Lutherans made up around 9.5 percent of the Transylvanian population in comparison with around 33 percent of Magyars, ${ }^{14}$ the Landeskundeverein had around 700 members by 1914, while the Museum Society recruited about 900 . 
Landeskunde societies in Germany, Austria, and Hungary had an interest in the local dimensions of their "fatherland," and aimed above all at the collection and publication of factual data about the localities and their inhabitants. Related to the early modern field of chorography and topography, Transylvanian Saxon Landeskunde too provided systematic descriptions of cities, including their natural surroundings, data about the population, livestock, agriculture, and trade, and one of its earliest tasks included a description of the "surroundings of Hermannstadt" already in 1843. The Landeskundeverein had sections in history and geography in the larger Transylvanian towns, featuring Hermannstadt, Kronstadt (Romanian name: Brașov, Hungarian name: Brassó), Schäßburg (Romanian name: Sighișoara, Hungarian name: Segesvár), Mediasch (Romanian: Mediaș, Hungarian: Medgyes), Mühlbach (Romanian: Sebeș, Hungarian: Szászsebes) but also in Vienna and Pest. ${ }^{15}$ It initiated and organized the study of "all the branches of Vaterlandeskunde,"16 yet it did not define its knowledge field in a systematic fashion, and the latter depended on the capacity and curiosity of the members. Indeed, the collective and collaborative work was essential for the gathering of relevant data both in an earlier Enlightenment encyclopedic and a later positivist configuration of factual knowledge on Transylvanian Saxon nature and culture and provided the empirical methodological basis of local history.

Most important in this regard was the historical source editing that had begun already in the late $1840 \mathrm{~s}$. By the turn of the century, this grew into a professional undertaking based on the international cooperation of trained archivists from the Habsburg Monarchy, in Germany and the Vatican. ${ }^{17}$ Yet despite its academic merits, the Landeskundeverein fashioned itself as a gathering of dilettanti instead of an institution of specialization- "it is not a society of learned men"- the goal being Bildung (self-formation) in general and not just the writing of learned treatises. ${ }^{18}$

\section{The Social Background and Its Impact}

Landeskunde scholars played a major role in putting the Transylvanian towns inhabited by Saxons on the cultural map of German-speaking Europe, by exploring their histories. The source publications and historical fragments constructed bygone urban cultures once under Transylvanian Saxon jurisdiction and administrative power, a power that began to crumble under the leveling Habsburg social reforms during the eighteenth century and became particularly fragile during the Dualist Hungarian rule. At a time when economic liberalization and the politics of Magyarization changed the demographic composition of the Transylvanian towns and brought powerful Romanian and Hungarian minorities into the Saxon towns, the exploration of the past acquired a peculiar twist.

The historical and cultural fragments and sources coagulated into a single national narrative, most important of which was certainly the History of the Transylvanian Saxons for the Saxon People, the first popular national history. ${ }^{19}$ The author was Georg Daniel Teutsch, who, on his academic peregrination in Germany, became a disciple of Ranke. Teutsch reinterpreted the premodern nation as a modern Saxon Kirchenvolk (community of faith) at a time when the traditional institutions of self-administration were just being crushed by the emerging modern state. ${ }^{20}$ His son, Friedrich, followed his father both in his profession as a bishop and as a prolific historian at the helm of the Landeskundeverein, ${ }^{21}$ which carried on the national romantic tone in its "heroic elevation of the past and the leading men." 22 Saxons were presented here as the "first ranking cultural factor" and "teaching master" of the Transylvanian "tribes," colonists who had been initially received and treated with respect by the Hungarian kings, only to be marginalized and antagonized by their descendants. ${ }^{23}$ These works became canonic historical texts and provided the framework for dealing with Saxon topics at the turn of the century. Hence, a national historicist and confessional perspective also on the urban space - one sought to document the traces of Reformation as "the great spiritual, moral, and religious rebirth" and as cultural ties to the 
protestant German "Motherlands," which stood in no contradiction with emphasizing national independence and distinction. ${ }^{24}$

Since the institutionalization of the humanities followed a national pattern, the consequence on the emerging urban cultural topographies was a tacit fragmentation by language and by assumed ethnic belonging. The interferences and conflicts resulting from antagonistic and mutually exclusive claims of appropriating urban spaces, based on ethnically organized learned societies, have been often discussed by historians after 1989. Indeed, by the eve of World War I, historical source publication, libraries, and museum collections organized according to the ethnonational principle played a crucial role in education and shaped the cultural horizon of the individual consumer.

Like the Teutsches, many Transylvanian Saxon students spent at least one semester at a German and Austrian university, most of whom became gymnasium professors and pastors upon their return home - and members of the Landeskundeverein. They were the motor of modern schooling, they organized also the related pedagogical and scholarly associations, and they championed German Bildung - in contrast to vocational and specialized education. ${ }^{25}$ Their intellectual profile determined the scholarly and thematic foci of the society. These included close bonds to secondary education and their curricula, and a broad historical interest in Saxon culture, its origins, its present stage and artifacts, as well as its legal basis. Looking at the publication record of the Archiv, it is possible to identify this Bildungsbürger (educated middle-class) clientele through even subtler thematic nuances, such as the growing number of articles on Saxon students at German universities. ${ }^{26}$

\section{Ethnic Mappings}

By the late nineteenth century, cultural history, complete with the history of confessions and humanist education under the auspices of the Lutheran Church, established itself at the expense of older Saxon and Transylvanian legal and political history. More general writings on ecclesiastical history alternated with data on individual churches, ecclesiastical chapters in the Königsboden (Romanian: Pământul Crăiesc, Hungarian: Királyföld), the border region to the Ottoman Empire, and bishoprics erected by the medieval German knight orders in Transylvania. The bulk of publications about these edifices by the fin-de-siécle linked the study of the confessional and military past with forays into urban history of Saxon settlements, as witnessed by a large amount of articles on the medieval and in early modern social and cultural history. ${ }^{27}$ They described the urban past both of the larger towns Kronstadt (Romanian: Brașov, Hungarian: Brassó), Mediasch (Romanian: Mediaș, Hungarian: Medgyes), Schässburg (Romanian: Sighișoara, Hungarian: Segesvár), Bistritz (Romanian: Bistrița, Hungarian: Beszterce), Sächsisch Regen (Romanian: Reghin, Hungarian: Szászrégen), and so on, as well as those once mighty military headquarters which became by the turn of the century smaller and more rural settlements: Birthälm (Romanian: Biertan, Hungarian: Berethalom), Grossschenk (Romanian: Cincu, Hungarian: Nagysenk), Reps (Romanian: Rupea, Hungarian: Köhalom), and the like. Examples from the public lectures delivered at the yearly meetings of the association exemplify this micro-historical emphasis: "Fragments about the older history of Hermannstadt," 28 "Historical novelties about Mediasch," 29 "Achaeological sketches from Schässburg,"30 "From the history of Bistritz from 1600 until 1604,"31 "Buda during the reign of the Anjou dynasty and its relations to Hermannstadt," 32 "From the guild life of Agnetheln," 33 and so forth. These lectures were then published by the association journal.

Statistically by far best documented was Hermannstadt, the historic administrative and political seat of the early modern Saxon natio. The urban topography was presented in a historicist fashion. Hermannstadt hosted occasionally the Transylvanian Diet and possessed one of the richest city archives in Transylvania. There was a strong focus on the sixteenth and early seventeenth 
centuries, the former figuring as the golden age of Saxon urban culture, followed by decline due to the incorporation into the Habsburg jurisdiction.

The image of the early modern city administration emerging from these studies presents a socially and ethnically diverse milieu under the guidance of the Saxon city magistrate, whose workings were often found as a leading example for the present. ${ }^{34}$ Although the studies do not efface the multilingual and multidenominational past of the city (as well as other cities), the focus is on the Saxon political administration and on the Lutheran, that is, Saxon cultural edifices.Even the smaller collections of sources were linked to the key themes of the national narrative, concerning scholarship, Protestantism, heroism, and determination before internal and external foes. Telling are, for instance, the published fragments of the earliest news from Hermannstadt concerning Sachs von Harteneck (1664-1703), mayor of Hermannstadt, whose biography was enshrined in the national historical narrative about Habsburg Counter-Reformation in seventeenth-century Transylvania, and the conflicts between the Saxon, Hungarian, and Székely estates. ${ }^{35}$ One would search in vain for the evidence of Romanian cultural edifices in the contemporary Saxon publications, the most important of which appeared in the Baedeker (see the introduction to this essay): they were not part of the Saxon scholarly agenda.

It is certainly a specificity of the Saxon cultural context in which the urban topography was produced that the topic intermingled with the portraiture of smaller settlements. This applied to the former military, ecclesiastic, and commercial nods in the medieval border zone to the Ottoman Empire, which lost prominence to the new infrastructural and industrial centers, and by 1900 had sunk to the status of villages. These harbored the Transylvanian Saxon church fortresses whose registration as protected artistic monuments had begun as early as the $1850 \mathrm{~s},{ }^{36}$ as well as remnants of religious orders and bishoprics founded by the Saxon settlers in Transylvania. The mapping of such settlements, regarded as monuments of the past, included not only the towns but also the countryside and led to an imaginary continuum between these two types of habitation.

Their exploration started at that time when the Landeskundeverein joined the monarchy-wide program for the registration and preservation of historical monuments in the $1850 \mathrm{~s}$. The jounal Jahrbuch der k.k. Central-Kommission zur Erforschung und Erhaltung der Baudenkmale (Yearbook of the Imperial and Royal Central Commission for the Research and Preservation of Historic Buildings) was the broader Viennese avenue for introducing the treasures of the Saxon past to the German-speaking scholarly audience beyond Transylvania. ${ }^{37}$ The fortresses acquired new popularity in the late 1880s, when the newfangled Siebenbürgischer Karpatenverein (Transylvanian Carpathian Association, 1880-1945) launched its own documentation of the rural and natural environment for touristic and preservationist purposes. ${ }^{38}$

In the last quarter of the nineteenth century, the church fortresses were increasingly regarded as rural in character, although cities used to possess them too. Contributions in the Archiv dated their rise to the centuries of Reformation and Counterreformation and presented them as symbols of national resistance, the defense bastions of Saxon legal autonomy and of Saxon Protestantism. This strategy was particularly visible in a popular series written by Friedrich Teutsch for the Yearbook of the Carpathian Association. ${ }^{39}$ It contained short Baedeker-type descriptions of all church fortresses in Transylvania built by Saxons and served as orientation for tourists. The target audience was German or had an intimate knowledge of the German fortresses on the Rhine or in Thuringia, as these served as the starting point and comparative background for presenting the subject. In the introductory part, Teutsch found the distinguishing features of the Transylvanian fortresses in their essentially "peasant" character in contrast to the putatively more hierarchical societies that erected similar edifices in the Holy Roman Empire. Teutsch's urban society was cast as a bond of equal and free men; unlike its counterpart in the German lands, it was presented as an early democracy. The rural communities were found equally democratic; here too "nobody was either a servant or a master." 40 
All in all, urban and rural environments were not presented in a radically different fashion, due to a strong cultural historical focus with a national scope. Such a perspective ignored the traces and effects of modern urban development and industrialization; neither had a concern for the developing infrastructure of public transport. The emphasis on the "national antiquities" contributed to the musealization of a predominantly mono-culturally conceived urban landscape, with an emphasis on preservation.

Saxon collective identity was built on confession and culture and references to autonomy. The presupposition of the eminent role of Saxons in Bildung was mediatized in the Korrespondenzblatt and also on occasion of the public lectures at the yearly celebrations of the Transylvanian Saxon civic movement, which served as the political orientation of the audience. ${ }^{41}$ The so-called Vereinstage (association days) gradually became a national celebration that involved other Saxon voluntary associations and lasted several days. Held each time at a different town, they involved the local Saxon community and were crowned by a festive mass held by the Saxon Bishop, and selected guests from the local, national, and international academic and political elite. Accomplished maps and painted images, later lithographs, of Saxon townscapes were prepared and sold here, thus demonstrating that not only the production but also the consumption of cultural goods was an important part of the agenda. ${ }^{42}$ During the two decades before the turn of the century, the Vereinstage (association days) grew into a celebration of the educational morale, regarded as the epitomes of Saxonness. "Our 'associations' are in some respects even more Saxon than our Church, as the latter includes some, although insignificant, splinters of the Magyar people," so the comment of a chronicler of the association days. ${ }^{43}$ In a time of social fragmentation, the Landeskundeverein symbolically created the unity of the town and village, young and old, peasant and Bildungsbürger as an imagined community of Transylvanian Germans. Here, the Hungarian state was mentioned, if at all, as a disturbing coercive force.

\section{Conclusion}

The conjuncture of local history emerged at a point when Landeskunde sought to accommodate divergent social backgrounds and political tastes, including even works with a markedly populist character. Some writings were intended for a larger audience and especially the younger generation so that they did not "lose the continuity of our historical sense of community." The populist tone seldom stirred scholarly criticism. ${ }^{44}$ The art historian Victor Roth chastised as one of the few critical scholars the image of the pristine Saxon cultural landscape and demanded instead comparative historical analysis. In his reply, the president of the Landeskundeverein, Friedrich Teutsch, defended dilettantism as the price of writing popular works, which transported the scholarly message to the masses: "except for the so-called 'educated,' how many businessmen, artisans, (and) village teachers are sharing the pleasure of scholarship . . . [n]ot to mention the peasants, who do not read our works?"45

This was of course a too modest answer; the growing scholarly community increasingly engaged with the perusal of local history by that time. Yet the establishing scientific ethos in the humanities, based on internationally shared, standardized methods, had a double effect. On one hand, it fostered exchange between the selected circles of Transylvanian and international experts. At the same time, urban history became firmly embedded into an ethno-culturally defined public culture, which strengthened the social cohesion between the "Saxon" towns and the countryside and separated these from the ethnic others.

\section{Declaration of Conflicting Interests}

The author declared no potential conflicts of interest with respect to the research, authorship, and/or publication of this article. 


\section{Funding}

The author received no financial support for the research, authorship, and/or publication of this article.

\section{Notes}

1. Ludwig Reissenberger, "Über die ehemaligen Befestigungen von Hermannstadt (aus dessen Nachlaß herausgegeben). Im Anhang 19 Urkunden und 4 Kartenbeilagen," Archiv des Vereins für siebenbürgische Landeskunde (hereafter referred to as Archiv) 29 (1900): 315-417; R. Rösler, "Beitrag zur Geschichte desZunftwesens. Älteres Zunftwesen in Hermannstadt bis zum Jahre 1526," Archiv 38 (1912): 443-551.

2. Joseph Ritter von Kürzböck, Almanach de Vienne, en faveur des étrangers, ou abrégé historique indiquant ce que la ville de Vienne renferme de plus remarquable et de plus curioux (Vienna, 1773), Baedeker's Austria. Including Hungary, Transylvania, Dalmatia, and Bosnia: Handbook for Travellers (Karl Baedeker: Leipsic [sic], 1900); H. M., "Die erste Hermannstädter Kunstausstellung," Korrespondenzblatt 10 (1887): 105-111; Gustav Seiwert, "Beiträge zu einer Geschichte der Hermannstädter Münzkammer," Archiv 6 (1864): 153-200; Archiv 6 (1865): 299-327.

3. M. V. Kimakowicz, "Studien zur Baugeschichte der ev. Stadtpfarrkirche in Hermannstadt," (9 Abb.), Archiv 39 (1913): 477-508.

4. Friedrich Teutsch, "Geschichte des ev. Gymnasiums A.B. in Hermannstadt," Archiv 17 (1882): 1-132; Archiv 19 (1884): 326-497; Friedrich Teutsch, "Die Rektoren des Hermannstädter Gymnasiums [17581876]," Korrespondenzblatt 7 (1884): 52.

5. Vasile Bologa, Monografia şcoalei civile de fete cu internat şi drept de publicitate a "Asociațiunii pentru literatura română şi cultura poporului roman," din Sibiiu, pe 25 de ani dela înființare [Monograph of the Girls' Normal School with a Boarding School, copyright by ASTRA] (Sibiu: Tiparul Tipografiei Arhidiecezane, 1911).

6. Victor Slăvescu, Banca Albina din Sibiu cea mai însemnată întreprindere financiară din Transilvania. $\mathrm{Cu}$ o privire generală asupra băncilor comerciale din Ardeal şi Banat [The Albina Bank in Hermannstadt (as) the Most Important Financial Enterprise in Transylvania. With an Overview on the Commercial Banks in Transylvania and Banat] (Bucharest: Inst. de Ed. "Reforma Socială," 1919).

7. Iosif Sterca Şuluțiu, Discursurile Prezidentului Asociațiunii, Iosif Sterca Sulutiu de Carpenis, cu ocaziunea serbărilor Asociațiunii ținute în Sibiiu la 19 August n. 1905 și zilele următoare [The Lectures of the President of the Association, Iosif Sterca Sulutiu de Carpenis, on Occasion of the Celebrations of the Association on 19 August 1905 and the Following Days] (Sibiu: Tipariul tipografiei arhidiecezane. 1905); Octavian C. Tăslăuanu, "Muzeul Asociațiunii raport asupra situației sale din 1912 şi date privitoare la organizarea şi sporul colecțiilor din anii 1908-1912 [The Museum of the Association, Report about its State in 1912 and Data about the Organization and Growth of the Collections in 1908-1912]," Transilvania nr. 4-5 (1913): 323-26.

8. Magyarország vármegyéi és városai (Magyarország monografiája): a Magyar korona országai történetének, földrajzi, képzömüvészeti, néprajzi, hadügyi és természeti viszonyainak, közmüvedödési és közgazdasági állapotának enciklopédiája [The Counties and Towns of Hungary (Monograph of Hungary): Encyclopedia of the History, Geography, Art History, Ethnography, Military and Natural Historical Aspects, Cultural and Economic Relations of the Lands of the Hungarian Crown], vols edited by Sziklay János és Borovszky Samu (Budapest: “Apollo” Irodalmi És Nyomdai Részvénytársaság, 1896-[1914?], 17 vols).

9. Archiv, vols. 1 (1843), 2 (1845), Iof er paceween 1840 and 1848.omestic issues of Hungary 3 (1847): new series vols. 1-50 (1853-1944).

10. Franz Zimmermann edited the paper until the end of 1879, followed by Johann Wolff (1880-1886), Johann Roth (1887-1891), and Adolf Schullerus (1892-1910). Heinrich Herbert, "Geschichte des Vereins für siebenbürgische Landeskunde," Archiv 28 (1898): 139-236, 170.

11. Die Redaction [the editors], "Gruss und Bitte," Korrespondenzblatt, no. 1 (January 1887): 1-3. About the initial program see, "Unser Programm," Korrespondenzblatt, no. 1 (January 1878): 1-2.

12. Mohammed Rassem and Justin Stagl, eds., Statistik und Staatsbeschreibung in der Neuzeit, vornehmlich im 16-18 Jahrhundert. Bericht über ein interdisziplinäres Symposion in Wolfenbüttel, 25-27 September 1978 (Paderborn: Schöningh, 1980). 
13. Bericht über die Entstehung, die Schicksale und Leistungen des Vereins für siebenbürgische Landeskunde bis zum Jahr 1853 vom Vereins-Vorsteher (Hermannstadt: Georg v. Closius, 1853), 3-14; Jahresbericht des Vereins für siebenbürgische Landeskunde für das Jahr 1863-1864 (Hermannstadt: Georg v. Closius, 1864), 4-19; Jahresbericht des Vereins für siebenbürgische Landeskunde für das Jahr 1883-1884 (Hermannstadt: Georg v. Closius, 1864), 4-19; Jahresbericht des Vereins für siebenbürgische Landeskunde für das Jahr 1893-1894 (Hermannstadt: W. Krafft, 1894), 3-24; Jahresbericht des Vereins für siebenbürgische Landeskunde für das Jahr 1914 (Hermannstadt: W. Krafft, 1915), 3-23.

14. In 1914, the Saxon association registered 707 members, while its Hungarian counterpart had 900 members in its lists. See Pál Erdélyi, Az EME évkönyve (Kolozsvár, 1914), 13; Jahresbericht des Vereins für siebenbürgische Landeskunde für das Jahr 1914 (Hermannstadt: W. Krafft, 1915), 3-23. For a rough orientation, the census of 1900 counted around 233,000 Germans, 815,000 Magyars, 1,397,000 Romanians, and 32,000 other nationalities on the territory of Transylvania $\left(57,804 \mathrm{~km}^{2}\right)$. Irina Livezeanu, Cultural Politics in Greater Romania: Regionalism, Nation Building and Ethnic Struggle, 1918-1930 (Ithaca, NY: Cornell University Press, 1995).

15. Heinz Herbert, "Geschichte des Vereines für Siebenbürgische Landeskunde," Archiv 28 (1898): 139$236,158$.

16. The constituting assembly meeting from 1842 enlisted the disciplines of "statistics, geography, ethnography, topography, public law, and legal studies, and the fields pertaining to natural history," which provided the framework of the exploration of the "fatherland" throughout its time of existence. "Statuten des Vereins für Siebenbürgische Landeskunde," in Vereins-Album. Denkblätter der dritten Versammlung des Vereins für Siebenbürgische Landeskunde, ed. Benigni von Mildenberg (Hermannstadt, 1845).

17. Franz Zimmermann and Carl Werner, "Einleitung," in Urkundenbuch zur Geschichte der Deutschen in Siebenbürgen, ed. Franz Zimmermann, Carl Warner, and Georg Müller (Hermannstadt: Franz Michaelis, 1892), vii-xxx, accessed July 26, 2014, https:/archive.org/stream/urkundenbuchzur00mlgoog\#page/ n12/mode/2up; Károly Szabó and Árpád Hellebrant, Régi magyar könyvtár [Old Hungarian Library], Vol. I. Az 1531-töl 1711-ig megjelent magyar nyomtatványok könyvészeti kézikönyve [Bibliographical Handbook of Hungarian Printed Matter, 1531-1711] (1879), Vol. II. Az 1473-1711-ig megjelent nem magyar nyelvü hazai nyomtatványok jegyzéke [Bibliography of Non-Hungarian Prints in Transylvania, 1473-1711] (1885), Vols. III-IV. A magyar szerzőktől külföldön 1480-tól 1711-ig megjelent nem magyar nyelvü nyomtatványok könyvészeti kézikönyve [Bibliography of Non-Hungarian Prints by Hungarian Authors Published Abroad, 1480-1711] (1896, 1898).

18. Herbert, "Geschichte des Vereines," 150.

19. Georg Daniel Teutsch, Geschichte der Siebenbürger Sachsen für das sächsische Volk, vols. 1-2 (2nd ed., Leipzig, 1874).

20. Ibid., 86. Andreas Möckel, "Geschichtsschreibung und Geschichtsbewustsein bei den siebenbürger Sachsen," in Studien zur Geschichtsschreibung im 19. und 20. Jahrhundert, ed. Philippi, 1-23, at 7-9.

21. Andreas Möckel, "Einführung," in Georg Daniel Teutsch and Friedrich Teutsch, Geschichte der siebenbürger Sachsen für das sächsische Volk, edited by Friedrich Teutsch, reprint edition with an introduction by Andreas Möckel, Vol. 1 (Böhlau: Cologne and Vienna, 1984), v-xxii, at vi-ix.

22. Ibid., 374 .

23. Ibid.

24. Adolf Armbruster, "Vorarbeiten zu einer Geschichte der siebenbürgisch-sächsischen Historiographie," Südostdeutsches Archiv 19/20 (1976/1977): 20-52, 42-46.

25. Walter König, “Thesen zur 'Bildungsrevolution' bei den Siebenbürger Sachsen," in Beiträge zur siebenbürgischen Schulgschichte, ed. Walter König (Cologne: Böhlau, 1996), 273-313, 297-99.

26. See Mathilde Wagner, Register der Periodika des Vereins für Siebenbürgische Landeskunde, 18401944 (Gundelsheim am Neckar: Arbeitskreis für Siebenbürgische Landeskunde, 2005).

27. In the Archiv this amounted to forty-three writings per decade during the Reform Era, 47.5 per decade in the neo-absolutist era of the 1850s-1860s, and 43.6 per decade coinciding with the Compromise, that is, 1871-1920. See Wagner, Register der Periodika.

28. Georg Schaser, "Bruchstücke aus der älteren Geschichte Hermannstadts," lecture given on May 31, 1844, Herbert, "Geschichte des Vereines," 215. 
29. Josef Bedeus Jun, "Historische Nachricht über Mediasch," lecture given on May 19, 1853, in ibid., 211.

30. Friedrich D. Müller, "Archäologische Skizzen aus Schässburg," lecture given on August 22, 1856, in ibid., 214.

31. Michael Kramer, "Aus der Geschichte von Bistritz in den Jahren 1600 bis 1604," lecture delivered on August 6, 1868, in ibid, 213.

32. Friedrich Schreiber, "Ofen zur Zeit der Anjous und seine Beziehungen zu Hermannstadt," lecture given on August 14, 1871, in ibid., 215.

33. Johann Roth, "Aus der Zunftszeit Agnethelns," lecture given on August 19, 1886, in ibid.

34. W. Schmidt, "Vier Jahre aus dem Leben eines autonomen siebenbürgischen Stadtmagistrates zu Anfang des achtzehnten Jahrhunderts. Ein Beitrag zu der Geschichte Hermannstadt's von 1717-1720, nach zeitgenössischen ämtlichen Aufzeichnungen," Archiv 7 (1866): 284-312.

35. Franz Zimmermann, "Hermannstädter lokalgeschichtliche Notizen aus dem 18. Jahrhundert," Korrespondenzblatt 6 (1883): 137-40.

36. Herbert, "Geschichte des Vereines," 173.

37. Konrad Gündisch, "Der Verein für Siebenbürgische Landeskunde. Eine Wissenschaftsgeschichte.” In Wege Landeskundelicher Forschung. 25 Jahre Arbeitskreis für Siebenbürgische Landeskunde, 19621987, edited by Konrad Gündisch (Cologne: Böhlau, 1988), 13-49, 23-24.

38. See Jahrbuch des Siebenbürgisches Karpatenvereins, vols 1-33 (Hermannstadt: XX, 1881-1944).

39. Friedrich Teutsch, "Unsere Burgen. Burgen bei Hermannstadt, in Jahrbuch des Siebenbürgischen Karpathen.Vereins, Vol. III. (Hermannstadt, 1883), 119-39.

40. Georg Adolf Schuller, "Die Gräfen" See Beyer, "Geschichtsbewustsein und Nationalprogramm der Siebenbürger Sachsen," in Studien zur Geschichtsschreibung im 19. und 20. Jahrhundert, ed. Paul Philippi (Köln-Graz: Böhlau, 1967), 56-115, 76, Gündisch, "Wissenschaftsgeschichte," 25.

41. Carl Göllner, Vortrag gehalten in der Versammlung des VSL, am 28 Mai 1847 in Großschenk (Kronstadt: Gött, 1847).

42. Herbert, "Geschichte des Vereines," 170-71.

43. Rudolf Briebrecher, "Unsere Vereine," in Vol. 2 of Bilder aus der vaterländischen Geschichte, ed. Friedrich Teutsch (Hermannstadt: W. Krafft, 1899), 480-91, 481.

44. Victor Roth, "Zur Geschichte der siebenbürgischen Kirchen-Architektur," Korrespondenzblatt no. 33 (1910): 64-70; Roth, "Zur Charakteristik der romanischen Kirchenarchitektur in Siebenbürgen," Korrespondenzblatt no. 34 (1911): 33-36; Roth, "Kritik und Wissenschaft. Eine Entgegnung auf Michael Auners 'Zur Geschichte des Abendmahlskelches in Siebenbürgen,"' Korrespondenzblatt no. 37 (1914): 73-96; Friedrich Teutsch, "Unsere Geschichtsschreibung in den letzten zwanzig Jahren, 1869-1889," Archiv 22 (1889): 619-687, 661-63.

45. Ibid., 684. Compare: "Verzeichnis der Akademien, Vereine und Gesellschaften, mit welchen der Verein für siebenbürgische Landeskunde in Verbindung steht, samt Angabe der im gegenseitigen Schriftentausche gewechselten Druckwerk," in Jahresbericht des Verein für siebenbürgische Landeskunde, 1879-1880, 25-33.

\section{Author Biography}

Borbála Zsuzsanna Török is Associate Fellow at Zukunftskolleg, University of Konstanz. Her research analyzes the configuration of scholarship in multiethnic and imperial settings, as in her coedited volume Negotiating Knowledge in Early Modern Empires (Palgrave Macmillan, 2014), and her monograph Exploring Transylvania: Geographies of Knowledge and Entangled Histories of a Multi-ethnic Province (Brill, 2015). 